Western North American Naturalist 69(3), (C) 2009, pp. 388-390

\title{
KARYOTYPES OF THE LONG-TAILED VOLE (MICROTUS LONGICAUDUS) IN ISOLATED MOUNTAIN RANGES OF THE AMERICAN SOUTHWEST
}

\author{
Jennifer K. Frey ${ }^{1,2,3}$, Benjamin J. Frey ${ }^{1,2}$, and Dwight W. Moore ${ }^{4,5}$
}

\begin{abstract}
The long-tailed vole (Microtus longicaudus) exhibits karyotypic variation in western North America. In the American Southwest, the species has a disjunct, relict distribution. However, karyotypes obtained from 20 specimens in 5 isolated mountain ranges (White Mountains, Arizona; Mount Taylor and the Sangre de Cristo, Jemez, and Mogollon mountains, New Mexico) exhibited no variation. These and previously reported karyotypes from the region had a diploid number $(2 \mathrm{n})$ of 56 and fundamental number $(\mathrm{FN})$ of 84 , which is the most commonly reported karyotype for the species.
\end{abstract}

Key words: long-tailed vole, Microtus longicaudus, chromosome, karyotype, American Southwest.

The long-tailed vole (Microtus longicaudus) is broadly distributed throughout western North America from Alaska south to southern California, Arizona, and New Mexico (Hall 1981, Smolen and Keller 1987). Whereas most species of voles (Microtus) from the North American mainland have a unique but invariant karyotype, considerable variation in chromosomal complement has been found in populations of Microtus longicaudus from the western United States. (Judd and Cross 1980; Table 1). The most widespread and commonly reported karyotype consists of 10 pairs of large- to medium-sized metacentric or submetacentric chromosomes, 12 pairs of large to small acrocentrics or subtelocentrics, and 5 pairs of small metacentric chromosomes (diploid number [2n] $=56$; fundamental number $[\mathrm{FN}]=84$ ). This form has been found in southeastern Washington, northwestern Oregon, Colorado, New Mexico, and Arizona (Matthey 1955, Hsu and Benirschke 1969, Judd and Cross 1980). Deviations from the $2 \mathrm{n}=56$ form have been found in the Cascade Range in southern Oregon and northern California $(2 \mathrm{n}=57,58,59,62,66$, and 70; Judd and Cross 1980), and also in northern Utah $(2 \mathrm{n}=64$; Modi 1985). These chromosome morphologies were similar to the $2 \mathrm{n}=56$ form except for the presence of 1-14 minute metacentric B chromosomes. Judd and
Cross (1980) also reported a pericentric inversion resulting in the absence of one pair of small acrocentric chromosomes and the presence of an extra pair of small metacentric chromosomes in populations from the Cascade Range (Table 1).

Microtus longicaudus reaches its southeastern range limits in the American Southwest (Hall 1981). There it is discontinuously distributed on isolated mountaintops, where it inhabits mesic coniferous forests (Smolen and Keller 1987). This distribution pattern was a product of post-Pleistocene vicariant fragmentation of formerly widespread coniferous forest habitats as a result of climatic warming (Frey et al. 2007). As a result of this isolation, disjunct populations exhibit considerable morphological variation, and 5 subspecies have been named (Findley and Jones 1962, Hoffmeister 1986). However, little is known about karyotypic variation within these highly isolated populations. Judd and Cross (1980) examined karyotypes from 3 populations, including the Jemez and Sacramento mountains in New Mexico and the White Mountains in Arizona. Each had the typical $2 \mathrm{n}=56$ form, although sample sizes for the Jemez $(n=3)$ and White $(n=1)$ mountains were small (Table 1). Consequently, the purpose of this study was to describe additional karyotypes from isolated

\footnotetext{
${ }^{1}$ Museum of Southwestern Biology, University of New Mexico, Albuquerque, NM 87131.

${ }^{2}$ Present address: Department of Fish, Wildlife, and Conservation Ecology, and The Vertebrate Museum, Department of Biology, New Mexico State University, Box 30003, Campus Box 4901, Las Cruces, NM 88003. E-mail: jfrey@nmsu.edu

${ }^{3}$ Present address: Frey Biological Research, Box 294, Radium Springs, NM 88054.

${ }^{4}$ Division of Biological Sciences and Schmidt Museum of Natural History, Emporia State University, Emporia, KS 66801.

${ }^{5}$ Present address: Aperio Scientific / ProPharma Group, 10975 Benson Drive, Suite 330, Overland Park, KS 66210.
} 
TABLE 1. Summary of known chromosome data for Microtus longicaudus, including diploid number (2n), number of pairs of small metacentric chromosomes $(\mathbf{M})$, number of metacentric B chromosomes $(\mathbf{B})$, and sample size $(n)$.

\begin{tabular}{|c|c|c|c|c|c|}
\hline Location & $2 n$ & M & $\mathrm{B}$ & $n$ & Reference \\
\hline \multicolumn{6}{|l|}{ Palouse / Northern Rocky Mountains } \\
\hline Washington, Whitman Co. & 56 & 5 & 0 & 1 & Matthey (1955) \\
\hline \multicolumn{6}{|l|}{ Columbia River } \\
\hline Oregon, Columbia Co. & 56 & 5 & 0 & 2 & Hsu and Benirschke (1969) \\
\hline \multicolumn{6}{|l|}{ Cascade Range } \\
\hline \multirow[t]{2}{*}{ Oregon, Jackson Co. } & 58 & 6 & 2 & 1 & Judd and Cross (1980) \\
\hline & 62 & 6 & 6 & 3 & \\
\hline \multirow[t]{2}{*}{ Oregon, Klamath Co. } & 57 & 6 & 1 & 2 & Judd and Cross (1980) \\
\hline & 59 & 6 & 3 & 1 & \\
\hline Oregon, Lake Co. & 66 & 6 & 10 & 3 & Judd and Cross (1980) \\
\hline \multirow[t]{2}{*}{ California, Siskiyou Co. } & 66 & 6 & 10 & 1 & Judd and Cross (1980) \\
\hline & 70 & 6 & 14 & 1 & \\
\hline \multicolumn{6}{|l|}{ Central Rocky Mountains } \\
\hline Utah, Weber Co. & 64 & 5 & 8 & 1 & Modi (1985) \\
\hline Utah, Salt Lake Co. & 64 & 5 & 8 & 1 & Modi (1985) \\
\hline \multicolumn{6}{|l|}{ Southern Rocky Mountains } \\
\hline Colorado, Larimer Co. & 56 & 5 & 0 & 1 & Judd and Cross (1980) \\
\hline New Mexico, Santa Fe Co. (Sangre de Cristo Mountains) & 56 & 5 & 0 & 5 & this study \\
\hline \multirow[t]{2}{*}{ New Mexico, Sandoval Co. (Jemez Mountains) } & 56 & 5 & 0 & 3 & Judd and Cross (1980) \\
\hline & 56 & 5 & 0 & 9 & this study \\
\hline New Mexico, Cibola Co. (Mount Taylor) & 56 & 5 & 0 & 3 & this study \\
\hline New Mexico, Lincoln Co. (Sacramento Mountains) & 56 & 5 & 0 & 10 & Judd and Cross (1980) \\
\hline New Mexico, Catron Co. (Mogollon Mountains) & 56 & 5 & 0 & 1 & this study \\
\hline \multirow[t]{2}{*}{ Arizona, Apache Co. (White Mountains) } & 56 & 5 & 0 & 1 & Judd and Cross (1980) \\
\hline & 56 & 5 & 0 & 2 & this study \\
\hline
\end{tabular}

populations of M. longicaudus in the American Southwest. This study includes examination of other specimens from the White and Jemez mountains as well as specimens from 3 additional mountain ranges in New Mexico, from which karyotypes have not previously been reported (i.e., Mount Taylor, Mogollon, and Sangre de Cristo mountains).

We prepared standard metaphase karyotypes from bone marrow cells of 20 wild-caught $M$. longicaudus following the procedure of Lee and Elder (1980; see Appendix for locations) and used a hypotonic solution of potassium chloride to facilitate the spreading of chromosomes. After completing the staining process, we scanned the slides under a microscope and selected chromosome spreads that yielded nonoverlap of chromosomes and the greatest detail of centromere position. We used a video monitor connected to the microscope to enlarge the image. We examined 5-10 chromosomal spreads for each specimen in order to establish a diploid number and chromosome structure.

All specimens examined had a $2 \mathrm{n}$ of 56 and an $\mathrm{FN}$ of 84 and were similar in structure to other $2 \mathrm{n}=56$ karyotypes previously reported for this species (Matthey 1955, Hsu and Benirschke 1969, Judd and Cross 1980). None of the specimens possessed supernumerary chromosomes or exhibited evidence of pericentric inversions.

In a phylogenetic analysis of the mitochondrial cytochrome $b$ gene (cyt-b), Conroy and Cook (2000) found that M. longicaudus was represented by at least 5 primary clades. The most divergent $c y t-b$ clade, which exhibited levels of differentiation equivalent to specieslevel differences in the genus, was found in the southern Rocky Mountains (i.e., including specimens from southeastern Wyoming, Colorado, New Mexico, and eastern Arizona) and corresponded to most of the distribution of the $2 \mathrm{n}=56$ karyotype described in this study (Table 1). However, other $2 \mathrm{n}=56$ specimens from the Palouse and Columbia rivers were from geographic regions contained in separate cyt-b clades. Lessa et al. (2003) found that the phylogenetic signal of $c y t-b$ within $M$. longicaudus in the American Southwest was consistent with historical demographic expansion rather than geographic subdivision. In contrast, no evidence for historical demographic expansion was observed for populations of $M$. longicaudus throughout much of the remainder of the continental U.S. Thus, the $c y t-b$ results appear to be generally consistent with the 
geographic patterns of karyotypic variation in M. longicaudus. Populations from the American Southwest are invariant, perhaps as a result of more recent colonization, while populations in much of the western U.S. are highly variable, perhaps as a result of longer periods of isolation. However, we caution that all reported karyotypes from southwestern $M$. longicaudus are from the same subspecies $(M$. l. longicaudus) and that examination of other, more-geographically isolated subspecies in Arizona may reveal additional variation. Finally, we recommend further analyses of the patterns of geographical concordance between karyotypic and molecular variation in this species.

This study was supported by a grant (to DWM) from the Faculty Research and Creativity Committee, Emporia State University. We thank the Museum of Southwestern Biology for a loan of karyotype slides.

\section{Literature Cited}

Conroy, C.J., AND J.A. Cook. 2000. Phylogeography of a post-glacial colonizer: Microtus longicaudus (Rodentia; Muridae). Molecular Ecology 9:165-175.

FindLEY, J.S., AND C.J. JoNES. 1962. Distribution and variation of voles of the genus Microtus in New
Mexico and adjacent areas. Journal of Mammalogy 43:154-166.

Frey, J.K., M.A. Bogan, And T.L. Yates. 2007. Mountaintop island age determines species richness of boreal mammals in the American Southwest. Ecography 30:231-240.

Hall, E.R. 1981. The mammals of North America. 2nd edition. John Wiley \& Sons, New York.

Hoffmeister, D.F. 1986. Mammals of Arizona. University of Arizona Press, Tucson.

Hsu, T.C., And K. BeniRschKe. 1969. An atlas of mammalian chromosomes. Volume 3, Folio 120. SpringerVerlag, New York.

JudD, S.R., AND S.P. CRoss. 1980. Chromosomal variation in Microtus longicaudus (Merriam). Murrelet 61:2-5.

LeE, M.R., AND F.F.B. Elder. 1980. Yeast stimulation of bone marrow mitosis for cytogenetic investigation. Cytogenetics and Cell Genetics 26:36-40.

Lessa, E.P., J.A. CooK., And J.L. Patton. 2003. Genetic footprints of demographic expansion in North America, but not Amazonia, during the late Quaternary. Proceedings of the National Academy of Science 100:10331-10334.

Matthey, R. 1955. Nouveaux documents sur les chromosomes des Muridae. Problèmes de cytologie comparèe et de taxonomie chez les microtinae. Revue Suisse de Zoologie 62:163-206.

Modi, W.S. 1985. Chromosomes of six species of New World microtine rodents. Mammalia 49:357-363.

Smolen, M.J., and B.L. Keller. 1987. Microtus longicaudus. Mammalian Species 271:1-7.

Received 31 October 2008

Accepted 15 April 2009

APPENDIX. Specimens examined and their geographic localities; NK numbers correspond to samples in the Museum of Southwestern Biology, University of New Mexico.

ARIZONA: Apache Co.-15.9 mi. S, 10.1 mi. E Springerville, Terry Flat, Escudilla Mountain, T6N, R31E, sec. 19 (NK 20115, NK 20116).

NEW MEXICO: Catron Co.-12.1 mi. E Mogollon, Willow Creek, T10S, R17W, NW 1/4 sec. 34 (NK 20131). Cibola Co._6 mi. N, 14 mi. E Grants, Mount Taylor, T12N, R7E (NK 9766, NK 9767, NK 9777). Santa Fe Co._5 mi. N, 8 mi. E Santa Fe (NK 1010, NK 1011, NK 1013, NK 1014, NK 1015). Sandoval Co.—3 mi. N, 9.5 mi. E Jemez Springs (NK 1703, NK 1706, NK 1708, NK 1710, NK 1712, NK 1714, NK 1715, NK 1716, NK 1718). 